\title{
Induction of Systematic Resistance in Soybean Plants against Fusarium Wilt Disease by Seed Treatment with Benzothiadiazole and Humic Acid
}

\author{
Montaser Fawzy ABDEL-MONAIM ${ }^{1}$, Mamdoh Ewis ISMAIL ${ }^{2}$, Karim Mohmed Morsy \\ ${ }^{1}$ Plant Pathology Research Institute, Agriculture Research Center, Giza, Egypt; ahmedismael91@yahoo.com \\ ${ }^{2}$ Minia University, Plant Pathology Departament, Faculty of Agriculture, Egypt
}

\begin{abstract}
The ability of benzothiadiazole (BTH), humic acid (HA) and their combination when used as seed soaking to induce systemic resistance against a pathogenic strain of Fusarium oxysporum was examined in four soybean cultivars under greenhouse conditions. Both inducers and their combination were able to protect soybean plants against damping-off and wilt diseases compared with check treatment. These results were confirmed under field conditions in two different locations, Minia and New Valley governorates. The tested treatments significantly reduced damping-off and wilt diseases and increased growth parameters, except number of branches plant ${ }^{-1}$, and seed yield. Application of BTH $(0.25)+\mathrm{HA}(4 \mathrm{~g} / \mathrm{l})$ was the most potent in this respect treatment. Soybean seed soaking in BTH + HA recorded the highest activities of the testes of oxidative enzymes followed by BTH in the four soybean cultivars. Whereas, HA treatment was recorded the lowest increased of these oxidative enzymes. Also, similar results were obtained in case of total phenol but $\mathrm{HA}$ increased the total phenol more than BTH in all tested cultivars.
\end{abstract}

Keywords: benzothiadiazole, humic acid, soybean,treatment, wilt disease

\section{Introduction}

Soybean (Glycine max L.) is one of the world's most important sources of oil and protein. It has the highest protein content among leguminous crops (El-Abady et al., 2008). Soybean plants are subjected to attack by several fungal, bacterial and viral diseases that cause great losses in the yield. Wilt disease of soybean plant caused by $F$. oxysporum is one of the most destructive serious diseases of the crop and is a very common soil-borne fungus (Hashem et al., 2009; Fayzalla et al., 2009). This pathogen is difficult to control because of their persistence in the soil and wide host range. Some chemicals are effective in controlling this disease but these chemicals are expensive and not environmental friendly. Therefore, alternative control methods are needed for managing this pathogen. Several alternative measures are being tested, including induce resistance by using biotic and abiotic treatments. The phenomenon of systemic induced resistance (SIR), in which resistance to disease is enhanced in tissues distant from the site of the prior inducing treatment, has been extensively reported for a number of plant/pathogen systems and has been the subject of recent reviews (Hammerschmidt, 1999). The majority of these studies have been conducted under controlled environment conditions. However, for SIR to be incorporated into applied disease management programs the resistance must withstand disease and environmental pressures encountered under commercial production conditions. Systemic induced resistance has been demonstrat- ed under field conditions for a limited number of plant/ pathogen interactions. Induced resistance in some plants against root diseases was reported by Sarwar et al. (2005), Abd-El-Kareem (2007). A new product, promoted as a safe, reliable, and nonphytotoxic plant protection agent, benzothiadiazole (BTH), was recently identified by scientists at Novartis as a novel disease-control compound. Exogenous application of BTH to tobacco, wheat and Arabidopsis leaves has been shown to activate a number of SAR-associated genes, leading to enhanced plant protection against various pathogens (Friedrich et al., 1996; Görlach et al., 1996; Lawton et al., 1996). These studies provided evidence that induction of SAR gene expression by BTH did not require the contribution of salicylic acid and/or jasmonate, suggesting that this compound could act as a secondary messenger analog capable of activating the SAR signal transduction pathway independently of the accumulation of other signal molecules (Lawton et al., 1996). In a recent ultrastructural investigation, Benhamou and Bélanger (1998) demonstrated that application of BTH to cucumber leaves before challenge with the root pathogen Pythium ultimum triggered a set of plant defense reactions that resulted in the creation of a fungitoxic environment, which protected the roots by restricting pathogen growth to the outermost tissues. Dann et al. (1998) reported that severity of white mold disease in field grown soybeans was significantly reduced by sprays of INA (2,6 dichloroisonicotinic acid) and BTH and increased of seed yield under field conditions. Sarwar et al. 
(2005) show that exogenously applied salicylic acid and $\mathrm{BTH}$ provided protection to chickpea plant against to infection with Fusarium oxysporum ciceri similar to that of Benlate.

HA is a suspension, based on potassium-humates, which can be applied successfully in many areas of plant production as a plant growth stimulant or soil conditioner for enhancing natural resistance against plant diseases (Scheuerell and Mahaffee, 2004), stimulation plant growth through increased cell division, as well as optimized uptake of nutrients and water and stimulated the soil microorganisms (Chen et al., 2004). Several reports indicated the efficiency of HA in reducing some plant diseases (Abd- El- Kareem, 2007; Yigit and Dikilitas, 2008; El-Mohamedy, and Ahmed 2009).

The use of inducers, BTH and HA substances would permit a reduction in the use of agrochemicals such fungicides. So, this investigation was done to evaluate effectiveness of BTH and HA treatments on control of wilt disease, of soybean under greenhouse and field conditions as well as seed yield. Also, biochemical changes associated with the application of the two inducers were assessed.

\section{Materials and methods}

\section{Isolation and identification of the causal pathogen}

Naturally diseased soybean plants showing wilt disease symptoms were collected from different localities of Minia and New Valley governorates in summer 2009 growing season. They were thoroughly washed in tap water, cut in small pieces $0.5 \mathrm{~cm}$ and surface sterilized for $2 \mathrm{~min}$ in $2 \%$ sodium hypochlorite solution, then several times in sterilized distilled water and dried between a number folds of sterilized filter papers. The surface sterilized samples were plated onto Potato Dextrose Agar (PDA) medium supplemented with penicillin $\left(20 \mathrm{Iu} \mathrm{m}^{-1}\right)$ and incubated at 25 $\pm 1^{\circ} \mathrm{C}$ for 6 days. The developed fungal colonies were purified by single spore techniques then identify according to Booth (1985).

\section{Pathogenicity test}

Eight $F$. oxysporum isolates obtained from diseased soybean plants were tested for pathogenicity on cv. 'Giza 21'. This experiment was carried out at New Valley Agric. Res. Station, in pots infested soil using the homogenized culture technique according to the method devised by Muthomi et al. (2007).

\section{Preparation of fungal inoculum}

Disk of pure culture of each isolate from different locations of $F$. oxysporum prepared from one week old culture was inoculated in $75 \mathrm{ml}$ Potato Dextrose (PD) broth medium in flask $250 \mathrm{ml}$ and incubated at $25 \pm 1{ }^{\circ} \mathrm{C}$., then collected on No. 1 Whattman filter paper and rinsed with sterile distilled water. The inoculum was placed in a warring blender with a small a mount of sterile water and blended for $2 \mathrm{~min}$ at high speed. Sterile distilled water was then added to each inoculum suspension to give a final concentration of $10^{6}$ colony forming unit $(\mathrm{CUF} / \mathrm{ml})$. Five replications of $100 \mathrm{ml}$ each of inoculum were used, 5 days before planting. Five replications of $100 \mathrm{ml}$ of sterile distilled water served as a control. Five seeds were sown in each pot $(30 \mathrm{~cm})$. Percentage of damping-off was recorded 30 days after seeding. Survival of survived plants healthy and infested was calculated 3 months after seeding. Healthy survival plants no visual evidence of disease. While severity of wilt was determined after 90 days according to Abdou et al. (2001) using a rating scale of 0 to 5 on the basis of root the discoloration or leaf yellowing as follows, $0=$ neither root discoloration nor leaf yellowing, $1=1-25 \%$ root discoloration or one leaf yellowed, $2=$ $26-50 \%$ root discoloration or more than one leaf yellowed, $3=51-75 \%$ root discoloration plus one leaf wilted, $4=$ up to $76 \%$ root discoloration or more than one leaf wilted, and $5=$ completely dead plants. For each replicate a disease severity index (DSI) similar to that described by Liu et al. (1995) was calculated as follows:

$$
D S I=\frac{\Sigma d}{d \max x n} X 100
$$

Where as: DSI is the disease rating possible, $\mathrm{d}$ max is the maximum disease rating and $\mathrm{n}$ is the total number of plants examined in each replicate.

Re-isolation of the pathogen from the infected plants was also done to confirm the causal agent of wilting.

Control of damping-off and wilt diseases caused by $F$. oxysporum under greenhouse condition

In this experiment, benzothiadiazole (BTH, Benzo-(1, 2,3) thiadiazole-7-carbothioic acid S-methyl ester wettable granule $50 \%$ WG, Bion ${ }^{\mathrm{R}}$ ) and humic acid (HA, Potassium humate soluble granule $85 \%$ WSG, Humus ${ }^{\mathrm{R}}$ ) were used as seed soaking for $20 \mathrm{~min}$ to evaluate their efficiency for controlling damping-off and wilt diseases caused by $F$. oxysporum of soybean in pots. Five soybeans (cvs. 'Giza 21', 'Giza 22', 'Giza 35' and 'Giza 111') seeds per pot were sown in 30- cm pots filled sterilized F. oxysporum infested soil at the rate of $100 \mathrm{ml}$ homogenized culture per pot as previously mentioned, 5 day before planting. The treatments were as follows: $\mathrm{BTH}$ at 0.25 and $0.5 \mathrm{~g} / \mathrm{l}$ a.i., $\mathrm{HA}$ at 2.5 and $5 \mathrm{~g} / \mathrm{l}$ a.i. as well as a combination of BTH and $\mathrm{HA}$ at $0.25 \mathrm{~g} \mathrm{BTH}$ and $2.5 \mathrm{~g} \mathrm{HA}, 0.25 \mathrm{~g} \mathrm{BTH}$ and $5 \mathrm{gm}$ $\mathrm{HA}, 0.5 \mathrm{gm} \mathrm{BTH}$ and $2.5 \mathrm{gm}$ Humic, $0.5 \mathrm{gm} \mathrm{BTH}$ and 5 gm HA each one litter. The control treatment was soil infested with F. oxysporum and sown with untreated soybean seeds at the same rate. A set of five pots for treatment were used. Each pot received equal amounts of water. Other agricultural processors were performed according to normal practice. Percentage of damping-off and wilt severity were recorded 30 and 90 days after seeding, respectively as above. 
82

\section{Field experiment}

Field experiment was carried out at two localities i.e., New Valley Agric. Res. Station and Experimental Farm of Plant Pathol. Dept, Fac. Agric, Minia Univ. during the growing summer season of 2010. Soybean seeds cvs. 'Giza 21', 'Giza 22', 'Giza 35', 'Giza 111' were soaked in the same tested treatments in greenhouse for $20 \mathrm{~min}$., then dried for 30 min before seeding while, in control treatment seeds were soaked in distilled water as mentioned above. Treated soybean seeds were sown in the field at the 4 th of May 2010 in both locations. A split plot design with three replicates was used in these experiments, the main plots represented varieties while sub-plots represented treatments. The area of each sub-plot was $10.5 \mathrm{~m}^{2} 3.0 \times 3.5$ containing five rows, each row was $3.5 \mathrm{~m}$ in length and distance between rows was $60 \mathrm{~cm}$. All treatments were sown in hills $20 \mathrm{~cm}$ apart on both sides of row ridge and two seeds per hill (plant population $=140,000$ plants $/$ fed $)$. All recommended agricultural practices were adopted throughout the two locations. After 30 days from seeding date, damping-off was determined. Wilt severity was also recorded on a random sample of plants of the sub -plots (20 plants) three months after seeding according to Abdou et al. (2001) described before.

At harvest stage, plant growth parameters plant height, number of branches and pods plant ${ }^{-1}$ and seed weight ten fed. ${ }^{-1}$ was recorded.

Effect of soybean seed treatment with inducer chemicals on enzymes activity and phenol content:

Activity of peroxidase (PO), polyphenol oxidase (PPO), phenylalanine ammonia lyase (PAL) enzymes and total phenol contents (TPC) was studied in tissue extracts of soybean plants emerged from treated with BTH at 0.5 $\mathrm{g} / \mathrm{l}$, HA at $5 \mathrm{~g} / \mathrm{l}$ as well as a combination of BTH $0.25 \mathrm{~g}$ $/ 1$ and HA $4 \mathrm{~g} / \mathrm{l}$ and untreated seeds. All treatments were grown in soil infested with $F$. oxysporum pathogen.

One gram of plant tissue was homogenized in $10 \mathrm{ml}$ of ice-cold $50 \mathrm{mM}$ potassium phosphate buffer ( $\mathrm{pH} 6.8$ ) containing $1 \mathrm{M} \mathrm{NaCl}, 1 \%$ polyvinylpyrrolidone, (PVP), 1 mM EDTA and $10 \mathrm{mM} \beta$-mercaptoethanol (Biles and Martyn, 1993). After filtration through cheesecloth, the homogenates were centrifuged at $8000 \mathrm{rpm}$ at $4^{\circ} \mathrm{C}$ for 25 $\min$. The supernatants (crude enzyme extract) were stored at $-20^{\circ} \mathrm{C}$ or immediately used for determination POX, PPOX and PAL enzymes activities and total protein. In the case of every enzyme under investigation, each treatment consisted in four replicates (3 plants/ replicate) and two spectrophotometric readings using Milton Roy Spectrophotometer (Milton Roy spectronic1201) were taken per replicate. The experiment for bioassays was repeated twice in time.

\section{Peroxidase activity}

The enzyme activity of PO was determined a direct spectrophotometrically method (Hammerschmidt et al.,
1982) using guaiacol as common substrate for peroxidases. The reaction mixture consisted of $0.2 \mathrm{ml}$ crude enzyme extract and $1.40 \mathrm{ml}$ of a solution containing guaiacol, hydrogen peroxide $\left(\mathrm{H}_{2} \mathrm{O}_{2}\right)$ and sodium phosphate buffer $\left(0.2 \mathrm{ml} 1 \%\right.$ guaiacol+ $+0.2 \mathrm{ml} 1 \% \mathrm{H}_{2} \mathrm{O}_{2}+1 \mathrm{ml} 10 \mathrm{mM}$ potassium phosphate buffer), was incubated at $25^{\circ} \mathrm{C}$ for $5 \mathrm{~min}$ and the initial rate of increase in absorbance was measured over $1 \mathrm{~min}$ at $470 \mathrm{~nm}$ using spectrophotometer. Peroxidase activity was expressed as units of $\mathrm{POX} / \mathrm{mg}$ protein (Urbanek et al., 1991).

\section{Polyphenoloxidase activity}

The activity of PPO was determined by adding $50 \mu \mathrm{l}$ of the crude extract to $3 \mathrm{ml}$ of a solution containing $100 \mathrm{mM}$ potassium phosphate buffer, $\mathrm{pH} 6.5$ and $25 \mathrm{mM}$ pyrocatechol. The increase of absorbance at $410 \mathrm{~nm}$, for $10 \mathrm{~min}$ at $30^{\circ} \mathrm{C}$, was measured (Gauillard et al., 1993). One PPOX unit was expressed as the variation of absorbance at 410 $\mathrm{nm}$ per milligram of soluble protein per minute.

\section{Phenylalanine ammonia layse activity}

Phenylalanine ammonia-layse (PAL) activity was determined following the direct spectrophotometric method adapted by Cavalcanti et al. (2007). Two hundred microlitres of the crude enzyme extract previously dialyzed overnight with $100 \mathrm{mM}$ Tris- $\mathrm{HCl}$ buffer, $\mathrm{pH} 8.8$, were mixed to obtain a solution containing $200 \mu \mathrm{l} 40 \mathrm{mM}$ phenylalanine, $20 \mu \mathrm{l} 50 \mathrm{mM} \beta$-mercaptoethanol and $480 \mu \mathrm{l}$ $100 \mathrm{mM}$ Tris-HCl buffer, $\mathrm{pH}$ 8.8. After incubation at $30^{\circ} \mathrm{C}$ for $1 \mathrm{~h}$, the reaction stopped by adding $100 \mu \mathrm{l} 6 \mathrm{~N} \mathrm{HCl}$. Absorbance at $290 \mathrm{~nm}$ was measured and the amount of trans-cinnamic acid formed was evaluated by comparison with a standard curve (0.1-2 $\mathrm{mg}$ trans-cinnamic acid $/ \mathrm{ml})$ and expressed as units of PAL $\mathrm{min}^{-1} \mathrm{mg}$ protein $^{-1}$.

\section{Protein concentration}

Total protein content of the samples was quantified according to the method described by Bradford (1976).

\section{Determination of phenolic compounds}

To assess phenolic content, $1 \mathrm{~g}$ fresh plant sample was homogenized in $10 \mathrm{ml} \mathrm{80 \%} \mathrm{methanol} \mathrm{and} \mathrm{agitated} \mathrm{for} 15$ min. at $70^{\circ} \mathrm{C}$. One $\mathrm{ml}$ of the extract was added to $5 \mathrm{ml}$ of distilled water and $250 \mu \mathrm{l}$ of $1 \mathrm{~N}$ Folin-Ciocalteau reagent and the solution was kept at $25^{\circ} \mathrm{C}$. The absorbance was measured with a spectrophotometer at $725 \mathrm{~nm}$. Catechol was used as a standard. The amount of phenolic content was expressed as phenol equivalents in $\mathrm{mg} \mathrm{g}^{-1}$ fresh tissue (Saikia et al., 2006).

\section{Statistical analysis}

All experiments were performed twice. Analyses of variance were carried out using MSTAT-C program version 2.10 (1991). Least significant difference (LSD) was employed to test for significant difference between treatments at $\mathrm{P} \leq 0.05$ (Gomez and Gomez, 1984). 


\section{Results}

\section{Pathogenicity test and identification of the causal organism (s)}

The eight fungal isolates obtained from different naturally infected soybean plants showing wilt symptoms were able to cause damping-off and wilt symptoms on artificial inoculated soybean. Data present in Tab. 1 showed that the highest percentage of damping-off and wilt were caused by isolate FO1 followed by isolate FO 6, while the least infection was expressed by isolate FO5. All the obtained isolated were identified as Fusarium oxysporum according to the descriptions of Booth, (1985) and confirmed by Assuit University Mycological Center (AUMC).

\section{Effect of Bion, HA on damping-off and wilt diseases caused by Fusarium oxysporum.}

\section{A) Under green house conditions}

Data present in Tab. 2 reveal that both the tested chemical inducers individually or combinations, in most cases, were significantly effective in reducing infection with $F$. oxysporum under greenhouse conditions compared with the check treatment (control). This reduction reached its maximum when combination between $\mathrm{BTH}$ and $\mathrm{HA}$ was used at 0.25 and $4 \mathrm{~g} / \mathrm{l}$ followed by 0.5 and $2 \mathrm{gm} / \mathrm{l}$ for all the tested cultivars. BTH and HA at 0.25 and $4 \mathrm{~g} / \mathrm{l}$ reducing the average damping-off and wilt for the four soybean cvs, i.e. 'Giza 21', 'Giza 22' , 'Giza 35' and 'Giza 111' from $36,28,36,20 \%$ damping-off and 57.33, 30.20, 49.18 and $24.37 \%$ wilt in control to $8,8,8,4 \%$ damping-off and 8.81 , $6.33,11.33$ and $4.67 \%$ wilt, respectively. On the other hand, soybean seed treated with HA at $2 \mathrm{~g} / \mathrm{l}$ recorded the lowest redaction of damping-off for all the tested cultivars, while seed treated with BTH at $0.25 \mathrm{~g} / \mathrm{l}$ recorded the lowest wilt for the all tested cultivars. Also, the obtained results show considerable differences in the response of different soybean cultivars to infection with Fusarium oxysporum. Generally, soybean 'Giza 21' cv. revealed to be more susceptible to Fusarium oxysporum followed by 'Giza 35' and

Tab. 1. Pathogenicity with Fusarium oxysporum isolate isolated from soybean roots collected from El- Minia and New Valley governorates

\begin{tabular}{|c|c|c|c|c|}
\hline $\begin{array}{c}\text { F. oxysporum } \\
\text { isolates }\end{array}$ & Locations & $\begin{array}{c}\% \\
\text { Damping-off }\end{array}$ & $\begin{array}{c}\% \\
\text { Wilt }\end{array}$ & $\begin{array}{c}\text { \% Survival } \\
\text { plants }\end{array}$ \\
\hline FO1 & El-Minia & 36 & 57.67 & 6.33 \\
\hline $\mathrm{FO} 2$ & El-Minia & 28 & 40.25 & 31.75 \\
\hline FO3 & El-Minia & 20 & 35.28 & 44.72 \\
\hline FO4 & New Valley & 16 & 32.67 & 51.33 \\
\hline FO5 & New Valley & 12 & 15.38 & 72.62 \\
\hline FO6 & New Valley & 28 & 50.67 & 21.33 \\
\hline FO7 & New Valley & 28 & 44.25 & 27.75 \\
\hline FO8 & New Valley & 20 & 38.84 & 41.16 \\
\hline \multicolumn{2}{|c|}{ LSD at 0.05} & 3.79 & 5.51 & 4.80 \\
\hline
\end{tabular}

'Giza 22' cvs., respectively. Whereas, 'Giza 111' was the least affective one, where gave less damping-off and wilt.

\section{B) Under field conditions}

The effect of the resistance inducers HA and BTH individually or combination at different concentrations on damping-off and wilt of four soybean cultivars under field conditions are shown in Tabl. 3 and 4. The obtained data show that all treatments, in most cases, caused significant reduction in the percentage of damping-off and wilt severity compared with control in both locations and the combination between HA and BTH decreased the percentage of damping-off and wilt severity in both locations than the used individually for the tested soybean cultivars. Soybean treated with combination between BTH and $\mathrm{HA}$ at concentration $0.25+4 \mathrm{~g} / \mathrm{l}$ caused the highest protection against to infection with damping-off and wilt diseases, where led to the decreased of the average damping-off in New Valley location from 18.33, 14.25, 23.67, 9.33\% in control to 5.33, 6.67, 6 and 2.67\% and in Minia location, this treatment reduced damping-off from $22.33,18.25$, 25.67 and $11.33 \%$ in control to $6.67,6.67,7$ and $3 \%$ for the four soybean tested cultivars i.e Giza 21, Giza 22, Giza 35 and Giza 111, respectively. Also, the wilt symptoms were reduced from 21.41, 10.67, 27.67 and $10.20 \%$ in control to $3,2.67,7.33$ and $2.15 \%$ in New Valley location and from $25.41,13.67,26.67$ and $12.20 \%$ in control to $5,3.33$, 10.33 and $2.56 \%$ in Minia location for the tested soybean cultivars, respectively. On the other hand, soybean treated with $\mathrm{HA}$ at $2 \mathrm{~g} / \mathrm{l}$ recorded the least redaction and not significant of damping-off disease compared with control in both locations, wile soybean treated with BTH at $0.25 \mathrm{~g} / \mathrm{l}$ recorded the lowest wilt severity for the tested cultivars in both locations compared with control.

In general, BTH was highly effective to reduced incidence of damping-off in seedling stage than $\mathrm{HA}$ but in contrary in case of wilt disease for the tested cultivars in both locations and also the four tested cultivars were infected with damping-off and wilt diseases either in New Valley or in El-Minia governorates and 'Giza 35' cv. was the most susceptible to infection followed by 'Giza 21' and 'Giza 22' cvs., respectively. Meanwhile, cv. 'Giza 111' was the least susceptible ones.

\section{Effect of BTH and HA on growth parameters and seed} yield under field conditions

Data present in Tabl. 5 and Tab. 6 demonstrated that the various responses of the four tested soybean cultivars at their growth parameters (plant height and number of pods/plant) and seed yield / feddan as affected by different concentrations of BTH and HA either individually or combination under Minia or New Valley governorates conditions. Results indicate that all treatments significantly improved plant height and increased on number pods plant ${ }^{-1}$ and seed yield fed. ${ }^{-1}$ in comparing with those of check treatment for the all the tested cultivars, while 
Tab. 2. Effect of BTH and HA on damping-off and wilt diseases caused by F. oxysporum isolate FO1 of the four soybean cultivars under greenhouse conditions

\begin{tabular}{|c|c|c|c|c|c|c|c|c|c|}
\hline \multirow{3}{*}{ Treatments } & \multirow{3}{*}{$\begin{array}{c}\text { Con. } \\
\text { (g/l a. i.) }\end{array}$} & \multicolumn{8}{|c|}{ Cultivars } \\
\hline & & \multicolumn{2}{|c|}{ 'Giza 21' } & \multicolumn{2}{|c|}{ 'Giza 22' } & \multicolumn{2}{|l|}{ 'Giza 35’ } & \multicolumn{2}{|c|}{ 'Giza 111' } \\
\hline & & $\begin{array}{l}\text { \% Damping- } \\
\text { off }\end{array}$ & $\%$ Wilt & $\begin{array}{l}\text { \% Damping- } \\
\text { off }\end{array}$ & \% Wilt & \% Damping-off & $\begin{array}{c}\% \\
\text { Wilt }\end{array}$ & $\begin{array}{l}\text { \% Damping- } \\
\text { off }\end{array}$ & \% Wilt \\
\hline \multirow{2}{*}{ Bion } & 0.25 & 32 & 20.00 & 20 & 28.00 & 28 & 34.72 & 12 & 17.85 \\
\hline & 0.50 & 16 & 17.94 & 16 & 12.40 & 16 & 15.33 & 8 & 12.11 \\
\hline \multirow{2}{*}{ HA } & 2 & 36 & 16.33 & 24 & 17.00 & 32 & 21.90 & 20 & 14.40 \\
\hline & 4 & 20 & 10.15 & 16 & 11.55 & 20 & 13.43 & 12 & 11.00 \\
\hline \multirow{4}{*}{$\begin{array}{c}\text { Bion } \\
+ \\
\mathrm{HA}\end{array}$} & $0.25+2$ & 16 & 16.40 & 12 & 10.63 & 20 & 17.62 & 16 & 8.73 \\
\hline & $0.25+4$ & 8 & 8.81 & 8 & 6.33 & 8 & 11.33 & 4 & 4.67 \\
\hline & $0.50+2$ & 12 & 10.42 & 8 & 9.37 & 12 & 12.39 & 8 & 6.25 \\
\hline & $0.50+4$ & 20 & 12.95 & 12 & 10.93 & 20 & 13.22 & 8 & 7.84 \\
\hline \multicolumn{2}{|c|}{ Control } & 36 & 57.33 & 28 & 30.20 & 36 & 49.18 & 20 & 24.73 \\
\hline \multicolumn{2}{|c|}{ LSD at $5 \%$} & 4.02 & 4.63 & 3.40 & 4.51 & 3.88 & 5.14 & 2.09 & 2.94 \\
\hline
\end{tabular}

Tab. 3. Effect of BTH and HA on damping-off and wilt diseases of the four soybean cultivars under field conditions in New Valley governorate at summer season 2010

\begin{tabular}{|c|c|c|c|c|c|c|c|c|c|}
\hline \multirow{4}{*}{ Treatments } & \multirow{4}{*}{$\begin{array}{c}\text { Con. } \\
\text { (g/l a. i.) }\end{array}$} & \multicolumn{8}{|c|}{ Cultivars } \\
\hline & & \multicolumn{2}{|c|}{ 'Giza 21' } & \multicolumn{2}{|c|}{ 'Giza 22' } & \multicolumn{2}{|c|}{ 'Giza 35’ } & \multicolumn{2}{|c|}{ 'Giza 111' } \\
\hline & & $\%$ & & $\%$ & & $\%$ & & $\%$ & \\
\hline & & $\begin{array}{c}\text { Damping- } \\
\text { off }\end{array}$ & \% Wilt & $\begin{array}{c}\text { Damping- } \\
\text { off }\end{array}$ & \% Wilt & $\begin{array}{c}\text { Damping- } \\
\text { off }\end{array}$ & $\%$ Wilt & $\begin{array}{c}\text { Damping- } \\
\text { off }\end{array}$ & \% Wilt \\
\hline \multirow{2}{*}{ Bion } & 0.25 & 12.33 & 9.33 & 11.67 & 9.00 & 17.33 & 16.33 & 7.33 & 6.53 \\
\hline & 0.50 & 10.33 & 7.30 & 10.67 & 7.33 & 11.33 & 14.33 & 5.33 & 4.36 \\
\hline \multirow{2}{*}{ HA } & 2 & 15.00 & 8.36 & 12.33 & 7.67 & 20.33 & 14.25 & 9.00 & 5.24 \\
\hline & 4 & 10.67 & 6.00 & 8.33 & 6.00 & 14.33 & 10.67 & 7.33 & 4.23 \\
\hline \multirow{4}{*}{$\begin{array}{c}\text { Bion } \\
+ \\
\text { HA }\end{array}$} & $0.25+2$ & 7.33 & 6.44 & 7.33 & 4.67 & 8.33 & 9.67 & 3.33 & 3.12 \\
\hline & $0.25+4$ & 5.33 & 3.00 & 6.67 & 2.67 & 6.00 & 7.33 & 2.67 & 2.15 \\
\hline & $0.50+2$ & 5.67 & 4.29 & 7.00 & 3.00 & 7.67 & 8.00 & 3.00 & 2.56 \\
\hline & $0.50+4$ & 9.33 & 7.20 & 7.67 & 5.14 & 10.33 & 8.39 & 4.33 & 3.82 \\
\hline \multicolumn{2}{|c|}{ Control } & 18.33 & 21.41 & 14.25 & 10.67 & 23.67 & 27.67 & 9.33 & 10.2 \\
\hline \multicolumn{2}{|c|}{ LSD at $5 \%$} & 3.47 & 3.40 & 3.17 & 2.54 & 3.97 & 4.38 & 2.33 & 2.07 \\
\hline
\end{tabular}

Tab. 4. Effect of BTH and HA on damping-off and wilt diseases of the four soybean cultivars under field conditions in Minia governorate at summer season 2010

\begin{tabular}{|c|c|c|c|c|c|c|c|c|c|}
\hline \multirow{4}{*}{ Treatments } & \multirow{4}{*}{ Con. (g/l) } & \multicolumn{8}{|c|}{ Cultivars } \\
\hline & & \multicolumn{2}{|c|}{ 'Giza 21' } & \multicolumn{2}{|c|}{ 'Giza 22’ } & \multicolumn{2}{|c|}{ 'Giza 35' } & \multicolumn{2}{|c|}{ 'Giza 111' } \\
\hline & & $\%$ & & $\%$ & & $\%$ & & $\%$ & \\
\hline & & $\begin{array}{c}\text { Damping- } \\
\text { off }\end{array}$ & \% Wilt & $\begin{array}{c}\text { Damping- } \\
\text { off }\end{array}$ & \% Wilt & $\begin{array}{c}\text { Damping- } \\
\text { off }\end{array}$ & \% Wilt & $\begin{array}{c}\text { Damping- } \\
\text { off }\end{array}$ & $\%$ Wilt \\
\hline \multirow{2}{*}{ Bion } & 0.25 & 16.67 & 12.23 & 15.00 & 12.00 & 23.67 & 19.33 & 10.33 & 9.53 \\
\hline & 0.50 & 12.33 & 9.20 & 9.67 & 8.14 & 16.33 & 13.67 & 6.33 & 6.82 \\
\hline \multirow{2}{*}{ HA } & 2 & 19.00 & 10.46 & 17.67 & 9.67 & 26.33 & 18.25 & 12.00 & 8.00 \\
\hline & 4 & 13.33 & 8.33 & 13.00 & 10.23 & 18.33 & 17.33 & 8.33 & 4.68 \\
\hline \multirow{4}{*}{$\begin{array}{c}\text { Bion } \\
+ \\
\text { HA }\end{array}$} & $0.25+2$ & 11.33 & 7.41 & 10.33 & 5.67 & 11.33 & 12.00 & 4.33 & 3.25 \\
\hline & $0.25+4$ & 6.67 & 5.00 & 6.67 & 3.33 & 7.00 & 10.33 & 3.00 & 2.56 \\
\hline & $0.50+2$ & 7.33 & 6.29 & 7.00 & 5.00 & 8.67 & 11.67 & 3.00 & 3.03 \\
\hline & $0.50+4$ & 10.00 & 7.00 & 12.00 & 7.17 & 16.33 & 12.39 & 9.33 & 5.53 \\
\hline \multicolumn{2}{|c|}{ Control } & 22.33 & 25.41 & 18.25 & 13.67 & 25.67 & 26.67 & 11.33 & 12.2 \\
\hline \multicolumn{2}{|c|}{ LSD at $5 \%$} & 4.01 & 3.57 & 4.66 & 3.04 & 4.50 & 5.17 & 2.70 & 2.37 \\
\hline
\end{tabular}


Tab. 5. Effect of BTH and HA on growth parameters of the four soybean cultivars under field conditions on New Valley governorate at summer season 2010

\begin{tabular}{|c|c|c|c|c|c|c|c|c|c|c|c|c|c|c|c|c|c|}
\hline \multirow[b]{3}{*}{ 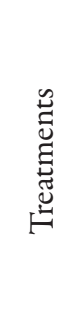 } & \multirow[b]{3}{*}{$\begin{array}{l}\text { Con } \\
(\mathrm{g} / \mathrm{l})\end{array}$} & \multicolumn{16}{|c|}{ Cultivars } \\
\hline & & \multicolumn{4}{|c|}{ 'Giza 21' } & \multicolumn{4}{|c|}{ 'Giza 22’ } & \multicolumn{4}{|c|}{ 'Giza 35’ } & \multicolumn{4}{|c|}{ 'Giza 111' } \\
\hline & & 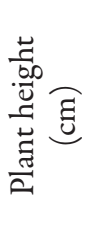 & 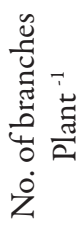 & 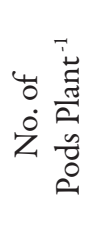 & 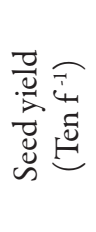 & 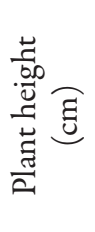 & 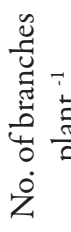 & 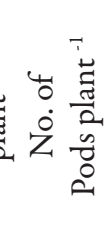 & 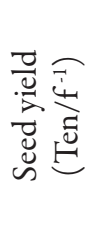 & 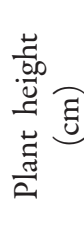 & 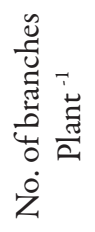 & 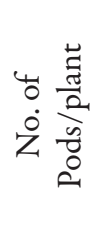 & 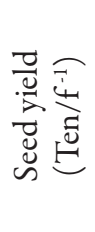 & 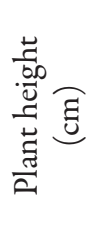 & 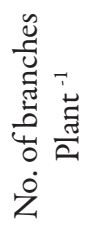 & 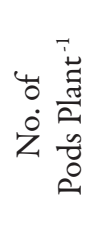 & 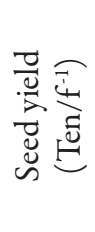 \\
\hline \multirow{2}{*}{ Bion } & 0.25 & 58.3 & 2.8 & 55.2 & 1.428 & 46.6 & 6.8 & 50.4 & 1.410 & 54.2 & 6.4 & 42.4 & 0.972 & 67.2 & 6.8 & 63.2 & 1.783 \\
\hline & 0.5 & 62.8 & 2.9 & 62.8 & 1.615 & 50.2 & 6.6 & 53.4 & 1.486 & 54.3 & 6.8 & 45.6 & 1.055 & 71.2. & 7.2 & 70.4 & 1.908 \\
\hline \multirow{2}{*}{$\mathrm{HA}$} & 2 & 60.5 & 3.0 & 65.4 & 1.566 & 47.3 & 7.2 & 55.8 & 1.562 & 55.3 & 6.4 & 46.0 & 1.062 & 69.2 & 7.0 & 66.8 & 1.826 \\
\hline & 4 & 64.3 & 3.0 & 67.4 & 1.699 & 55.3 & 7.4 & 58.2 & 1.635 & 56.2 & 7.0 & 50.2 & 1.154 & 76.5 & 7.4 & 74.2 & 1.987 \\
\hline \multirow{4}{*}{$\begin{array}{c}\text { Bion } \\
+ \\
\text { HA }\end{array}$} & $0.25+2$ & 62.5 & 3.2 & 68.4 & 1.661 & 49.3 & 7.0 & 57.0 & 1.599 & 55.2 & 6.6 & 49.2 & 1.135 & 71.3 & 7.0 & 69.4 & 1.89 \\
\hline & $0.25+4$ & 67.3 & 3.4 & 72.6 & 1.825 & 58.2 & 7.4 & 59.4 & 1.663 & 57.2 & 6.6 & 55.2 & 1.278 & 77.6 & 7.4 & 79.2 & 2.247 \\
\hline & $0.5+2$ & 66.2 & 3.1 & 70.4 & 1.796 & 56.5 & 7.2 & 57.2 & 1.601 & 60.2 & 6.8 & 53.4 & 1.225 & 75.4 & 7.4 & 76.8 & 2.097 \\
\hline & $0.5+4$ & 63.4 & 2.9 & 68.2 & 1.732 & 54.1 & 6.8 & 56.4 & 1.579 & 59.0 & 6.4 & 51.2 & 1.172 & 72.3 & 7.4 & 75.6 & 2.026 \\
\hline \multicolumn{2}{|c|}{ Control } & 53.5 & 2.8 & 50.1 & 1.195 & 41.8 & 6.6 & 40.2 & 1.118 & 50.3 & 6.2 & 39.2 & 0.826 & 64.5 & 7.0 & 56.5 & 1.502 \\
\hline \multicolumn{2}{|c|}{ LSD at $5 \%$} & 4.35 & NS & 3.99 & 0.251 & 3.58 & NS & 3.08 & 0.204 & 3.25 & NS & 2.47 & 0.208 & 3.81 & NS & 3.19 & 0.232 \\
\hline
\end{tabular}

the increase of number of branches plant non- significant in all tested cultivars in both locations. In this respect, the combination between at BTH and Humic acid at concentration 0.25 and $4 \mathrm{~g} / \mathrm{l}$ followed by 0.5 and $2 \mathrm{~g} / \mathrm{l}$ were the superior treatments, while BTH when used individually at $0.25 \mathrm{~g} / \mathrm{l}$ were the lest effective ones. On the other hand, soybean 'Giza 111' cv. gave the best results for growth parameters and seed yield in case of seed treated or untreated in both locations.
Biochemical changes associated with inducers compounds

A) Activity of peroxidase, polyphenol oxidase and phenylalanine ammonia lyase enzymes:

The effect of BTH and HA individually or combination as inducer chemicals on the activity of oxidative enzymes i.e. peroxidase (PO), polyphenol oxidase (PPO) and phenylalanine ammonia lyase (PAL) of four soybean cvs. grown in soil infested with $F$. oxysporum was studied and the obtained data are shown in Fig. 1 to 3. Both the

Tab. 6. Effect of BTH and HA on the growth parameters of the four soybean cultivars under field conditions Minia governorate at summer season 2010

\begin{tabular}{|c|c|c|c|c|c|c|c|c|c|c|c|c|c|c|c|c|c|}
\hline \multirow[b]{3}{*}{ 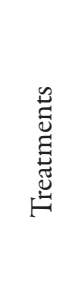 } & \multirow[b]{3}{*}{$\underbrace{\stackrel{\widehat{\sigma}}{0}}_{\overrightarrow{0}}$} & \multicolumn{16}{|c|}{ Cultivars } \\
\hline & & \multicolumn{4}{|c|}{ 'Giza 21' } & \multicolumn{4}{|c|}{ 'Giza 22' } & \multicolumn{4}{|c|}{ 'Giza 35’ } & \multicolumn{4}{|c|}{ 'Giza 111' } \\
\hline & & 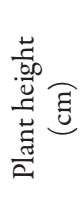 & 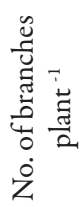 & 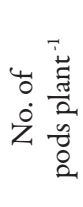 & 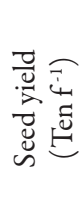 & 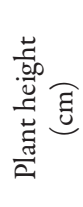 & 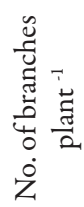 & 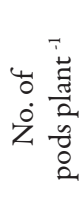 & 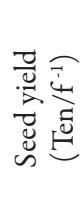 & 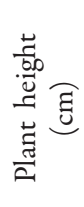 & 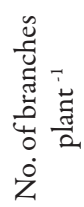 & 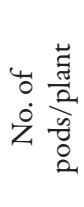 & 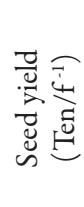 & 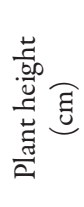 & 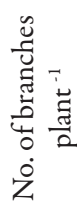 & 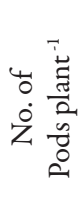 & 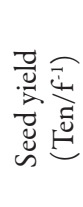 \\
\hline \multirow{2}{*}{ Bion } & 0.25 & 54.3 & 2.6 & 52.2 & 1.317 & 43.1 & 6.5 & 48.8 & 1.41 & 49.2 & 6.0 & 40.4 & 0.912 & 64.2 & 6.4 & 60.4 & 1.647 \\
\hline & 0.5 & 59.8 & 2.8 & 60.4 & 1.245 & 47.2 & 6.1 & 50.9 & 1.486 & 51.0 & 6.5 & 43.2 & 1.010 & 69.2 . & 7.0 & 67.8 & 1.825 \\
\hline \multirow{2}{*}{$\mathrm{HA}$} & 2 & 55.5 & 2.8 & 62.7 & 1.397 & 45.1 & 6.9 & 53.8 & 1.562 & 52.0 & 6.3 & 44.1 & 1.000 & 68.2 & 6.8 & 64.2 & 1.787 \\
\hline & 4 & 60.3 & 2.9 & 65.9 & 1.587 & 53.4 & 7.1 & 55.9 & 1.635 & 53.4 & 6.5 & 48.9 & 1.127 & 75.5 & 7.2 & 70.2 & 1.927 \\
\hline \multirow{4}{*}{$\begin{array}{c}\text { Bion } \\
+ \\
\text { HA }\end{array}$} & $0.25+2$ & 60.5 & 3.1 & 66.8 & 1.601 & 48.1 & 6.8 & 54.0 & 1.599 & 53.0 & 6.4 & 48.2 & 1.105 & 70.3 & 6.9 & 67.3 & 1.827 \\
\hline & $0.25+4$ & 66.3 & 3.5 & 70.1 & 1.775 & 56.4 & 7.3 & 58.6 & 1.663 & 54.2 & 6.2 & 54.2 & 1.218 & 75.6 & 7.3 & 77.2 & 2.137 \\
\hline & $0.5+2$ & 63.2 & 3.0 & 68.4 & 1.724 & 54.2 & 7.0 & 56.4 & 1.601 & 52.2 & 6.8 & 52.8 & 1.200 & 73.1 & 7.2 & 75.5 & 2.002 \\
\hline & $0.5+4$ & 61.4 & 2.5 & 66.0 & 1.654 & 51.3 & 6.4 & 53.0 & 1.579 & 54.0 & 6.3 & 49.8 & 1.151 & 70.0 & 7.0 & 74.6 & 1.979 \\
\hline \multicolumn{2}{|c|}{ Control } & 48.5 & 2.4 & 45.3 & 1.009 & 36.4 & 6.0 & 37.2 & 0.997 & 50.0 & 5.7 & 37.2 & 0.806 & 61.8 & 6.5 & 53.5 & 1.142 \\
\hline \multicolumn{2}{|c|}{ LSD at $5 \%$} & 3.17 & NS & 2.84 & 0.209 & 2.97 & NS & 2.57 & 0.261 & NS & NS & 2.04 & 0.244 & 3.66 & NS & 2.33 & 0.314 \\
\hline
\end{tabular}


86

$\boldsymbol{\square}$ Bion $\square$ Humic acid $\square$ Bion and Humia acid $\square$ control

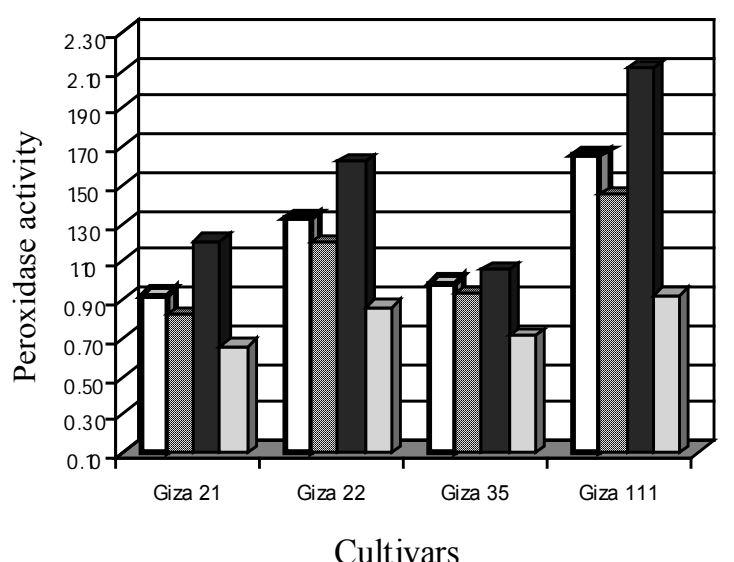

Fig. 1. Activity of peroxidase enzyme (enzyme unit $\mathrm{mg}_{\text {protein }}{ }^{-1}$ $\left.\min ^{-1}\right)$ of four soybean cultivars as affected by BHT $(0.5 \mathrm{~g} / \mathrm{l})$, HA $(4 \mathrm{~g} / \mathrm{l})$ individually or combination $(0.25+4 \mathrm{~g} / \mathrm{l})$

tested inducers increased the activity of PO, PPO, PAL enzymes in the four soybean tested cultivars either used individually or combination compared with untreated plants (control). The combination between BTH and HA possessed the highest change in oxidative enzymes followed by BTH when used as individually in the four soybean cultivars. Whereas, HA treatment was recorded the lowest increased of these oxidative enzymes. On the other hand, the susceptibility of the four soybean cvs. was positively correlated with the activity of these enzymes, where cv. 'Giza 111' (more resistant to F. oxysporum) as it recorded the highest enzymes activity and cv. 'Giza 21' (highly susceptible) recorded the lowest enzymes activity either in treated or untreated plants.

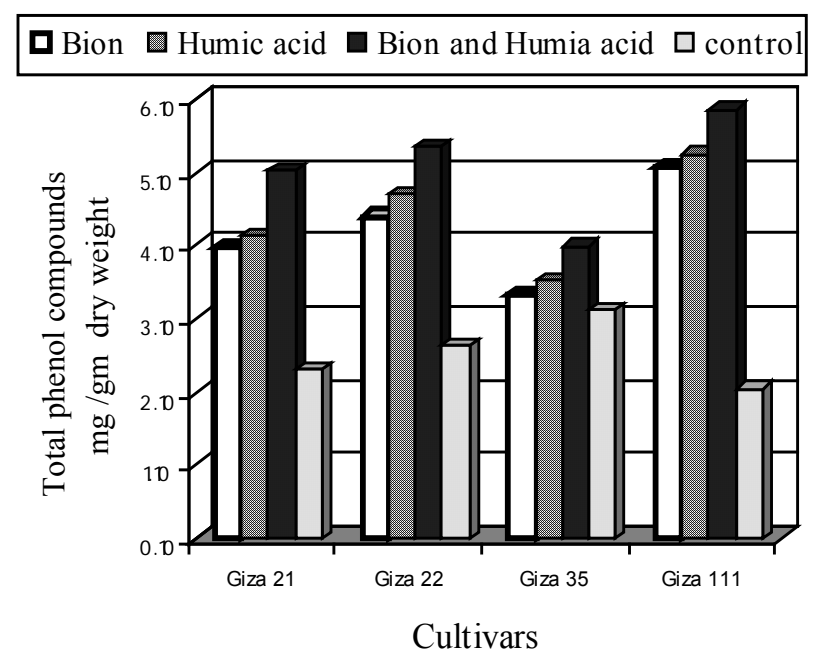

Fig. 3. Activity of phenylalanine ammonia lyase enzyme (enzyme unit $\mathrm{mg}$ protein $\mathrm{min}^{-1}$ ) of four soybean cultivars as affected by $\operatorname{BHT}(0.5 \mathrm{~g} / \mathrm{l}), \mathrm{HA}(4 \mathrm{~g} / \mathrm{l})$ individually or combination $(0.25+4$ $\mathrm{g} / \mathrm{l})$ $\boldsymbol{\square}$ Bion $\boldsymbol{\square}$ Humic acid $\boldsymbol{\square}$ Bion and Humia acid $\square$ control

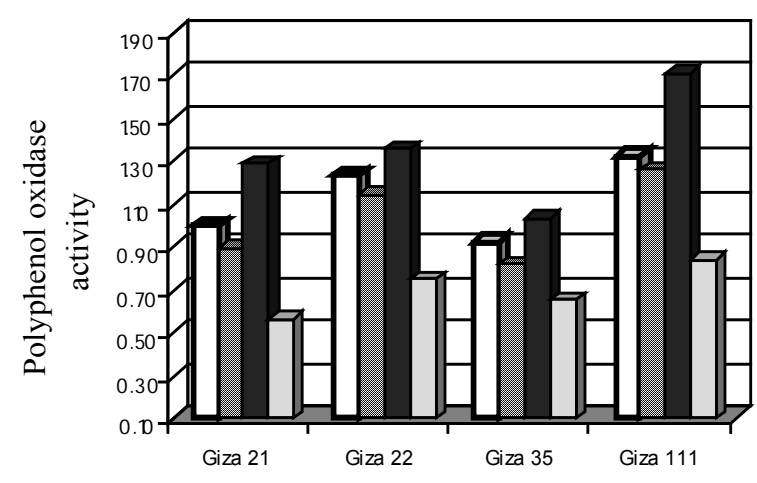

Cultivars

Fig. 2. Activity of peroxidase enzyme (enzyme unit $\mathrm{mg}$ protein ${ }^{-1}$ $\left.\mathrm{min}^{-1}\right)$ of four soybean cultivars as affected by BHT $(0.5 \mathrm{~g} / \mathrm{l})$, HA $(4 \mathrm{~g} / \mathrm{l})$ individually or combination $(0.25+4 \mathrm{~g} / \mathrm{l})$.

\section{B) Phenolic compounds content}

The total phenol compounds content were highly increased in plants treated with inducers compared with untreated ones in all the tested cultivars and the combination between $\mathrm{HA}$ acid and BTH increased the phenols content than used individually (Fig. 5). Soybean cultivars were differed in phenols content in treated and untreated plants, where soybean cv. 'Giza 111' was recorded the highest phenols content in case of treated plants followed by 'Giza 22', while 'Giza 35' was recorded the lowest ones. Meanwhile, in case of untreated plants the opposite trend was recorded.
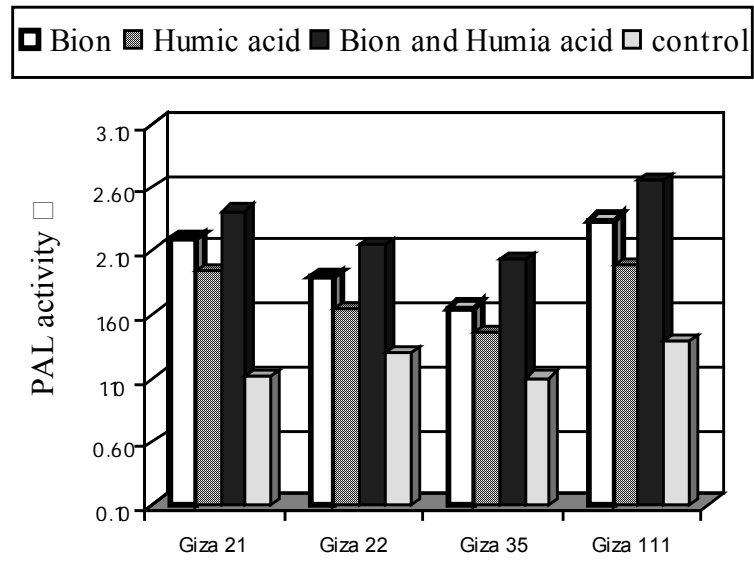

Cultivars

Fig. 4. Total phenol compounds (TPC) content of four soybean cultivars as affected by BHT ( $0.5 \mathrm{~g} / \mathrm{l}), \mathrm{HA}(4 \mathrm{~g} / \mathrm{l})$ individually or combination $(0.25+4 \mathrm{~g} / \mathrm{l})$ 


\section{Discussion}

Wilt disease caused by Fusarium oxysporum was the most important diseases attack soybean plants during growing season (Hashem et al., 2009; Fayzalla et al., 2009).

Also, under field condition, these chemicals significant increased growth parameters and seed yield fed-1 and the us $\mathrm{BTH}+\mathrm{HA}$ in combination resulted the highest increased in these characters compared with check treatment. Such results agree with those reported by Benhamou and Bélanger (1998), Sarwar et al. (2005) Abd-El-Kareem (2007), Nafie and Mazen (2008), Yigit and Dikilitas (2008), El-Mohamedy and Ahmed (2009).

Both compounds to induced disease resistance and increased yield in a number of plants including soybean and another legume (Lawton et al.,1996; Dann et al., 1998, Abd-El-Kareem, 2007; Nafie and Mazen 2008; El-Ghamry et al., 2009), against a broad range of pathogens. These compounds have no direct antimicrobial activity against many fungal and bacterial pathogens (Dann et al., 1998; Abd-El-Kareem, 2007). We suggest, therefore, that in soybean BTH and HA treatments may stimulate inherent defense mechanisms so that the plant can respond more quickly against the invading, colonizing fungus. It seems likely that increased activity of the enzymes involved in defense reactions may be one of the basic ways participate in the action of BTH and $\mathrm{HA}$ in inducing resistance in soybean against wilt disease. Thus, oxidative enzymes i.e. peroxidase (PO) polyphenol oxidase (PPO) and phenylalanine ammonia- layse (PAL) were increased in $\mathrm{BTH}, \mathrm{HA}$ and their combination- treated infected compared with untreated control plants. On the other hand, the susceptibility of the four soybean cvs. was positively correlated with the activity of these enzymes, where cv. 'Giza 111' (more resistant to F. oxysporum) as it recorded the highest enzymes activity and cv. 'Giza 21' (highly susceptible) recorded the lowest enzymes activity either in treated or untreated plants. Also, the total phenol compounds content were highly increased in plants treated with inducers compared with untreated ones in all the tested cultivars and the combination between BTH and HA increased the phenols content than used individually.

The role of $\mathrm{BTH}$ as an resistance inducer it was reported that induction of systemic acquired resistance (SAR) gene expression by BTH did not require the contribution of SA which suggest that this compound could act as a secondary messenger analog capable of activating SAR signal transduction pathway independently of the accumulation of other signal molecules (Lawton et al.,1996). Application of BTH to a variety of plants before challenge with the pathogens triggered a set of plant defense reactions that resulted in the creation of a fungitoxic environment, which protect them by different physical and / or chemical means mechanisms (Nafie and Mazen, 2008). Also, treatment with BTH and HA led to an increase in enzymatic activity of PO, PPO and PAL and many investigators reported that the expression of resistance is often accompanied by the activation of phenol-oxidizing enzymes such as PO, PPO and PAL (Goodman and Novacky, 1994). Increase in PO and PPO activity may contribute to defense through the production of oxidized forms of quinones, which can inactivate pectinolytic enzymes produced by pathogens. This suggests that $\mathrm{PO}$ and $\mathrm{PPO}$ could play an effective role in the observed resistance. PO and PPO have been associated with induced resistance and involved in several plant defense mechanisms, such as lignin biosynthesis, oxidative cross-linking of plant cell walls, and also generation of AOS (Faize et al., 2004). PAL is a key enzyme of phenylpropanoid pathway that leads to a variety of defense-related plant secondary metabolites such as SA, phytoalexins, and lignin-like polymers (Cools and Ishii, 2002). It has been shown to play a critical role in ASMmediated resistance, as its expression was primed early by ASM in Japanese pear (Faize et al., 2004) and cucumber (Cools and Ishii, 2002). However, the direct role of PAL in resistance induced by ASM comes from the work of Standik and Buchenauer (2000) who showed that chemical inhibition of PAL abolished resistance in wheat induced against Blumeria graminis f. sp. tritici.

On the other hand, data strongly suggest that HA directly or indirectly, plays as a signal for inducing systemic resistance as proposed by Abd-El-Kareem (2007). HA is a suspension, based on potassium humates, which can be applied successfully in many areas of plant production as a plant growth stimulant or soil conditioner for enhancing natural resistance against plant diseases and pests (Scheuerell and Mahaffee, 2004) which consequently increase yield of plant. Application of HA consistently enhanced antioxidants such as á-tocopherol, â-carotene, superoxide dismutases, and ascorbic acid concentrations in turf grass species (Zhang, 1997). These antioxidants may play a role in the regulation of plant development, flowering and chilling of disease resistance (Dmitrier et al., 2003). HA is considered to increase the permeability of plant membranes and enhance the uptake of nutrients. Moreover, it (HA) is also considered to improve soil nitrogen uptake and encourage the uptake of potassium, calcium, magnesium and phosphorus, making these more mobile and available to plant root system (Piccolo et al., 1997).

In conclusion, it could be suggested that combined treatment between BTH and HA as safety method might be used commercially for controlling soybean diseases under field conditions.

\section{References}

Abd-El-Kareem F (2007). Induced resistance in bean plants against root rot and Alternaria leaf spot diseases using biotic and abiotic inducers under field conditions. Research $\mathrm{J}$ of Agricultural and Biological Science 3(6):767-774.

Abdou El-S, Abd-Alla HM, Galal AA (2001). Survey of sesame 
88 root rot/wilt disease in Minia and their possible control by ascorbic and salicylic acids. Assuit J of Agric Sci 32(3):135152.

Benhamou N, Bélanger RR (1998). Induction of systemic resistance to Pythium damping-off in cucumber plants by benzothiadiazole: Ultrastructure and cytochemistry of the host response. The Plant J 14(1):13-21.

Biles CL, Martyn RD (1993). Peroxidase, polyphenoloxidase and shikimate dehydrognase isozymes in relation to tissue type, maturity and pathogen induction of watermelon seedling. Plant Physiol Biochem 31:499-506.

Booth C (1985). The genus Fusarium. Kew, Surrey Commonwealth Mycological Institute, $2^{\text {nd }}$ Ed., p. 237.

Bradford M (1976). A rapid and sensitive method for the quantitation of Microgram quantities of protein utilizing the principle of protein dye binding. Anal Biochem 72:248250.

Cavalcanti FR, Resendea MLV, Carvalhoc CPS, Silveirab JAG, Oliveira JTA (2007). An aqueous suspension of Crinipellis perniciosa mycelium activates tomato defense responses against Xanthomonas vesicatoria. Crop Prot 6:729-738.

Chen Y, De Nobili M, Aviad T (2004). Stimulatory effect of humic substances on plant growth, p. 103-130. In: Magdoff F and Weil RR 9eds.). Soil Organic Matter in Sustainable Agriculture Press, Boca Raton FL.

Cools HJ, Ishii H (2002). Pre-treatment of cucumber plants with acibenzolar-S-methyl systemically primes a phenylalanine ammonia lyase gene $(P A L)$ for enhanced expression upon fungal pathogen attack. Physiol Mol Plant Pathol 61:273 280.

Dann E, Diers B, Byrum J, Hammerschmidt R (1998). Effect of treating Soybean with 2,6- dichloroisonicotinic acid (INA) and benzothiadiazole (BTH) on seed yields and the level of disease caused by Sclerotinia sclerotiorum in field and greenhouse. Eur J Plant Pathol 104:271-278.

Dmitrier A, Tena M, Jorrin J (2003). Systemic acyuired resistance in sunflower (Helianthus annuus L.). Tsitologiya1-Genetika 37(3):9-15.

El-Abady MI, Seadh SE, Attia AN, El-Saidy Aml EA (2008). Impact of foliar fertilization and its time of application on yield and seed quality of soybean. The $2^{\text {th }}$ field crops conference, FCRI, AV, Giza, Egypt.

El-Ghamry Ayman M, Abd El-Hai KM, Ghoneem KM (2009). Amino and HAs promote growth, yield and disease resistance of faba bean cultivated in clayey soil. Australian J of Basic and Applied Sciences 3(2):731-739.

El-Mohamedy RSR, Ahmed MA (2009). Effect of biofertilizers and humic Acid on control of dry root rot disease and improvement yield quality of mandarin (Citrus reticulate Blanco). Res J of Agric Biological Sci 5(2):127-137.

Faize M, Faize L, Koike N, Ishizaka M, Ishii H (2004). Acibenzolar- $S$-methyl-induced resistance to Japanese pear scab is associated with potentiation of multiple defense responses. Phytopathology 94:604-612.

Fayzalla EA, El-Barougy E, El-Rayes MM, (2009). Control of soil-borne pathogenic fungi of soybean by biofumigation with mustard seed meal. J of Applied Sci 9:2272-2279.

Friedrich L, Lawton K, Ruess W, Masner P, Specker N, Gut MR, Meier B, Dincher S, Staub T, Uknes S, Metraux JP, Kessmann $\mathrm{H}$, Ryals J (1996). A benzothiadiazole derivative induces systemic acquired resistance in tobacco. Plant J 10:61-70.

Gauillard F, Richard-Forget F, Nicolas J (1993). New spectrophotometric assay for polyphenol oxidase activity. Anal Biochem 215:59-65.

Gomez KA, Gomez AA (1984). Statistical Procedures for Agricultural Research. A. Lviley. Interscience Publication. New York, p. 678.

Goodmann RN, Novacky AJ (1994). The bacteria-induced hypersensitive reaction, p. 117-173. In: The Hypersensitive Reaction in Plants to Pathogens. The American Phytopathological Society, St. Paul, MN.

Görlach J, Volrath S, Knauff-Beiter G, Hengy G, Beckhove U, Kogel KH, Oostendorp M, Staub T, Ward E, Kessmann $\mathrm{H}$, (1996). Benzothiadiazole, a novel class of inducers of systemic acquired resistance, activates gene expression and disease resistance in wheat. Plant Cell 8:629-643.

Guzzo SD, Back EA, Martins EM, Moraes WB (1993). Crude expolysaccarides (EPS) from Xanthomonas campestris pv. maniohtis, Xanthomonas campestris pv. campestris and commercial xanthan gum as inducers of protection in coffee plants against Hemileia vastatrix. J Phytopathol 139:119. 128.

Hammerschmidt R (1999). Induced disease resistance: how do induced plants stop pathogens?. Physiological and Molecular Plant Pathology 55(2):77-84.

Hashem EA, Abdalla HE, Hussein YA, Abd-Elnabi MA (2009). In vitro selection of soybean callus resistant to Fusarium oxysporum metabolites. Research J of Agric and Biological Sci 5(4):588-596.

Lawton K, Friedrich L, Hunt M, Weymann K, Delaney T, Kessmann H, Staub T, Ryals J (1996). Benzothiadiazole induces disease resistance in Arabidopsis by activation of the systemic acquired resistance signal transduction pathway. Plant J 10:71-82.

Liu L, Kloepper JW, Tuzun S (1995). Introduction of systemic resistance in cucumber against Fusarium wilt by plant growth-promoting rhizobacteria. Phytopathology 85:695698.

MSTAT-C, 1991. A Software Program for the Design, Management and Analysis of Agronomic Research Experiments. Michigan State University, p. 400.

Muthomi JW, Oteino PE, Chemining W, Nderitu JH, Wagacha JM (2007).Effect of legume root rot pathogens and fungicide seed treatment on nodulation and biomass accumulation. J of Biological Sciences 7(7):1163-1170.

Nafie E, Mazen M (2008). Chemical-Induced Resistance against 
Brown Stem Rot in Soybean: The Effect of Benzothiadiazole. J of Applied Sci Res 4(12):2046-2064.

Piccolo A, Nardi S, Concheri G (1992). Structural characteristics of humic substances as regulated to nitrate uptake and growth regulation in plant systems. Soil Biochem 24:373380.

Saikia R, Yadav M, Varghese S, Singh BP, Gogoi DK, Kuma R, Arora KD (2006). Role of riboflavin in induced resistance against Fusarium wilt and charcoal rot diseases of chickpea. Plant Pathol J 22(4):339-347.

Sarwar Nighat Z, Hayat ChM, Ikramul H, Jamil FF (2005). induction of systemic resistance in chickpea against Fusarium wilt by seed treatment with salicylic acid and Bion. PakJ Bot 37(4):989-995.

Scheuerell SJ, Mahaffee WH (2004). Compost tea as a container medium drench for suppressing seedling damping off caused by Pythium ultimum. Phytopathology 94:1156-1163.
Standik MJ, Buchenauer H (2000). Inhibition of phenylalanine ammonia-lyase suppresses the resistance induced by benzothiadiazole in wheat to Blumeria graminis f. sp. tritici. Physiol Mol Plant Pathol 57:25-34.

Urbanek H, Kuzniak-Gebarowska E, Herka H (1991). Elicitation of defense responses in bean leaves by Botrytis cinerea polygalacturonase. Acta Physiol Plant 13:43-50.

Yigit F, Dikilitas M (2008). Effect of humic acid application on the root- rot diseases caused by Fusarium spp. on tomato plants. Plant Pathology J 7(2):179-182.

Zhang X (1997). Influence of Plant Growth Regulators on Turfgrasss Growth, Antioxidant Status, and Drought Tolerance. Ph.D. thesis, Fac. of Virginia, USA. 